\title{
Evaluation of Interincisal Angle and Lip Position in Class II Division 1 Malocclusion Treatment with Upper Premolar Extraction
}

\author{
Elih Sayuti, Yuliawati Zenab \\ Faculty of Dentistry, Universitas Padjadjaran, Bandung, Indonesia \\ Email: elihortho@yahoo.co.id, yuliawatizenab.ort@yahoo.com
}

How to cite this paper: Sayuti, E. and Zenab, Y. (2019) Evaluation of Interincisal Angle and Lip Position in Class II Division 1 Malocclusion Treatment with Upper Premolar Extraction. Open Access Library Journal, 6: e5234.

https://doi.org/10.4236/oalib.1105234

Received: February 11, 2019

Accepted: February 25, 2019

Published: February 28, 2019

Copyright $\odot 2019$ by author(s) and Open Access Library Inc.

This work is licensed under the Creative Commons Attribution International License (CC BY 4.0).

http://creativecommons.org/licenses/by/4.0/

\begin{abstract}
Introduction: Protrusive anterior teeth in class II division 1 malocclusion cause the facial profile to become convex with anterior teeth retraction is expected to correct protrusive teeth and improve facial profile. The purpose of this study was to determine whether there was a change in lip position after incisor retraction in the treatment of class II division 1 malocclusion with extraction of maxillary premolars. This study was carried out on lateral cephalometry before and after treatment in 25 patients with class II division 1 malocclusion to evaluate changes in lip position with the Burstone method. To assess the results of treatment, statistical analysis was performed using t test and the Wilcoxon test. Result: The results of the comparison test of the facial profile of the upper lip and lower lip before and after treatment showed a p-value of 0.001 ( $p$-value $0.001<0.05$ ) meaning that there were significant differences in the position of the upper lip and lower lip before and after treatment using Burstone method. Conclusion: There is a change in facial profile after retraction of the anterior teeth in the treatment of class II division 1 malocclusion with extraction of the maxillary premolars.
\end{abstract}

\section{Subject Areas}

Dentistry

\section{Keywords}

Lip Position, Facial Profile, Incisor Retraction

\section{Introduction}

Class II Division 1 Angle Malocclusion has the characteristics of anterior teeth, 
deep bite, deep palate and convex profile. Convex face profile causes unattractiveness on patient's appearance, often called a bird face. Class II division $1 \mathrm{ma}-$ locclusion can be caused by a dental or skeletal abnormality [1] [2]. Treatment of class II division 1 skeletal malocclusion in adult patients is generally camouflage by extracting upper premolar teeth. Treatment with two premolar extractions is carried out to obtain a room with the aim of improving the protrusion of the anterior teeth by retracting the anterior teeth, so that changes in the inter incisal angle were obtained in order to improve the facial profile.

Facial profile usually represents the inclination of anterior teeth and the ideal incisive position has to be aligned in order to get a good facial balance after orthodontic treatment, with consideration of soft tissue thickness factor of each individual [3] [4]. Therefore, it is important to measure the relationship between anteroposterior position of incisive and soft tissue. There are various methods for determining changes in soft tissue profiles using cephalometric radiograph. One analysis of soft tissue is the Burstone method, conducted by measuring the distance of protrusion of the upper and lower lips against line $B$.

Previous studies have suggested that there is a relationship between incisive position and profile convexity and lip position [4]. However, according to Kasai (1998) soft tissue does not always follow dento-skeletal profile because soft tissue covering the teeth and alveolar bone has varying thickness and tension [5]. Lip response is not only affected by retraction of the anterior teeth but also influenced by the lip structure [6]. Some researchers also stated that it was difficult to predict lip position after incisive retraction, because it was affected by factors such as race, gender, type of malocclusion, and soft tissue thickness [5]. Because of the importance of soft tissue profiles in facial alignment and aesthetics, evaluation of soft tissue profile after treatmentis therefore needed to determine treatment plans and predict treatment outcomes.

The aim of this study was to evaluate the orthodontic treatment result according to interincisal angle and lip position in maloclussion class II division 1 treated with two upper premolar extractions in Orthodontics Residency Clinic Universitas Padjadjaran.

\section{Materials and Methods}

\subsection{Materials}

Twenty five lateral cephalometric radiograph before and after Class II division 1 maloclussion treatment in Orthodontics Residency Clinic Universitas Padjadjaran were obtained. Samples were 5 male patients and 20 female patients. Inclusion criteria of the samples were: a) Skeletal pattern Class II (ANB $\left.>4^{\circ}\right)$; b) permanent dentition period; c) obtain no agenesis; d) treatment plan using two upper premolar extractions; e) obtain no functional treatment; f) obtain no additional intraoral appliances. All samples obtained fixed orthodontic treatment using Edgewise standard method with two upper premolar extractions followed by retraction of canines and incisors. 


\subsection{Method}

Manual lateral cephalogram tracing was performed. Interincisal angle measurements were performed by calculating angles formed by the long axis lines of the maxillary incisors (IU) and mandibular incisors (IL) (Figure 1) [2]. Soft tissue profiles were measured based on the Burstonemethod using line $\mathrm{B}$, lines made from subnasal (SN) to soft tissue pogonion (PgS), from which the distance was measured to the upper and lower lip (Figure 2) [7].

The reliability test of this study was carried out by measuring at least 3 (three) times at different times. Then a statistical analysis test was carried out, if the data were not normally distributed then the analysis used was a non-parametric test using the Wilcoxon test, but if the data were normally distributed then the anal$y$ sis used was parametric tests using paired $t$ test.

\section{Results}

Interincisal angles before and after treatment of class II division 1 malocclusion treated with two upper premolar extractions followed by anterior teeth retractions were shown in Table 1.

Based on Table 1, of the 25 samples tested the results of the previous interincisal angle measurement had a minimum score of $91.5^{\circ}$, maximum score of $137.0^{\circ}$, a mean of $108.9^{\circ}$, with a standard deviation of 10.6 . While after treatment the minimum interincisal angle altered to $98.0^{\circ}$, the maximum value was $140.0^{\circ}$, the mean was $121.8^{\circ}$, with standard deviation of 9.4 .

The results of measurements of interincisal angle and soft tissue profile by measuring upper lip protrusion and lower lip protrusion based on the Burstone method on 25 patients before and after treatment can be seen in Table 2 .

After treatment of class II division 1 malocclusion with maxillary premolarsextraction followed by retraction of anterior teeth, it was shown that there was a significant change $(\mathrm{p}<0.05)$ at inter incisal angle with the increase of $12.9^{\circ}$. The results of the study of soft tissue profile on upper lip protrusion revealed that the upper lip protrusion was significantly reduced, as well as the lower lip protrusion in class II division 1 malocclusion with the extraction of two maxillary premolars.

\section{Discussion}

The purpose of orthodontic treatment is to get a harmonious tooth arrangement, optimal occlusion, facial profile and good aesthetics [3] [7] [8]. In order to get stable treatment results, a balance between the dental tissue and the muscles around the mouth is required. According to Holdaway, orthodontic treatment is closely related to changes in facial soft tissue [9]. There are several factors that affect soft tissue changes in retracting anterior teeth including tissue morphology, thickness, and muscle tone. Changes in the soft tissue profile of patients with extraction also depended on patient age and treatment techniques associated with incisor retraction [10]. 


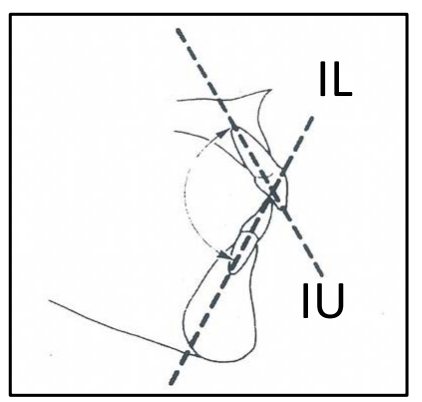

Figure 1. Measurement of interincisal angle using the upper incisor long axis lines (IU) and lower incisive long axis line (IL) [2].

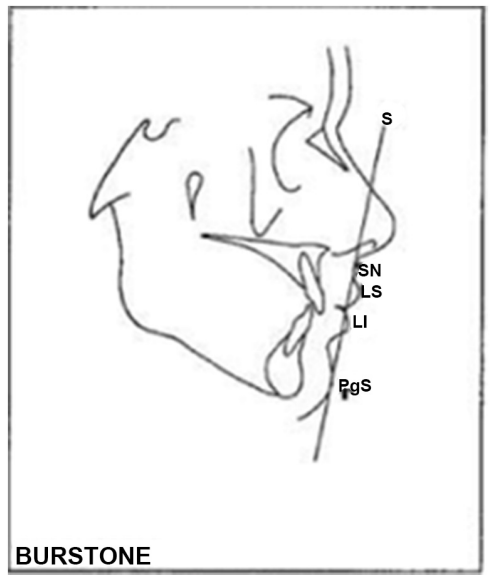

Figure 2. Burstones' soft tissue profile analysis. Measure the distance of protrusion of the upper and lower lips against line $\mathrm{B}$, which is a line made from subnasal (SN) to soft tissue pogonion (PgS) [7].

Table 1. Interincisal angles before and after treatment.

\begin{tabular}{cccccc}
\hline & $\boldsymbol{N}$ & Minimum & Maximum & Mean & Std. Deviation \\
\hline Before & 25 & 91.5 & 137.0 & 108.9 & 10.6 \\
After & 25 & 98.0 & 140.0 & 121.8 & 9.4 \\
\hline
\end{tabular}

Table 2. Interincisal angle measurement, upper lip protrusion, and lower lip protrution before and after treatment.

\begin{tabular}{cccccc}
\hline Variable & Before & $S D$ & After & $S D$ & $P$ value \\
\hline Interincisal Angle & 108.9 & 10.6 & 121.8 & 9.4 & $0.000^{\star}$ \\
IU (mm) & 7.6 & 2.2 & 5.8 & 2.2 & $0.001^{*}$ \\
IL (mm) & 7.2 & 2.8 & 4.9 & 2.8 & $0.000^{\star}$ \\
\hline
\end{tabular}

Ket: IU: upper lip protrusion, IL: lower lip protrusion, ${ }^{*}$-value $(0.000)<0.05$ : significant.

Based on the results of this study after treatment with extraction of two premolars followed by retraction of the anterior teeth it was found that the inter in- 
cisal angle increased by $12.9^{\circ}$ with an average of $121.8^{\circ}$ This is in accordance with study conducted by Kusnoto stated that the interrogative angle of detromalay was $130^{\circ} \pm 10^{\circ}$. Discrepancy in the interincisal angle in this study was in accordance with Basciftci's research, which showed that the amount of inter incisal angle was significantly reduced in the extraction group as a result of the incisor position [11]. However, the degree of incisal angle after treatment obtained from this study was not in line with the interincisal angle value obtained by Down $\left(135.4^{\circ} \pm 5.8^{\circ}\right)$.The discrepancy of the degree may be affected by the different samples used. Samples used in Down's study were mainly Caucasian, while samples of this study was the Deutro Malay race. Besides, the difference in interincisal angle can also be caused by the results of treatment influenced by several factors such as the amount of torque during retraction, alveolar bone condition, different individual responses and the number of samples.

The results showed reducing of the upper lip protrusion. The protrusion distance of the upper lip before treatment was $7.6 \mathrm{~mm}$ and after treatment was 5.6 $\mathrm{mm}$, with the discrepancy of $1.8 \mathrm{~mm}$. The result was in line with result of study conducted by Hagler et al. (1998) which showed that retraction of the maxillary incisors retruded maxillary lips up to $2 \mathrm{~mm}$ [12]. Kusnoto et al. (2001) showed that for each millimeter of incisal retraction, upper lip was retracted by $0.4 \mathrm{~mm}$ [13]. While Talaas et al. (1987) stated that the retraction ratio of upper incisors to upper lip retraction was 4.3: $1.9 \mathrm{~mm}$ [14]. Similarly, Kasai (1998) stated that maxillary incisor retraction was $4.3 \mathrm{~mm}$ causes upper lip to retrude $1.9 \mathrm{~mm}$ [15]. The results of study conducted by Rains et al showed that the ratio of retraction to upper incisors with upper lip retraction was 8:5, the mean of incisor retraction was $3.1 \mathrm{~mm}$ resulted in upper lip retraction of $1.9 \mathrm{~mm}$. According to Rains, the upper lip response was related to upper and lower incisors movement, mandibular rotation, and lower lip position [16].

The results of the study of soft tissue profiles on the lower lip showed significant changes at the end of treatment with two premolars extractions followed by retraction of the anterior teeth. The mean distance of the lower lip and line B before treatment was $7.2 \mathrm{~mm}$ and the mean distance after treatment was $4.9 \mathrm{~mm}$, thus protrusion of the lower lip was reduced by $2.3 \mathrm{~mm}$.

Kocadereli (2002) and Hagler et al. (1998) showed that premolar extractions followed by anterior teeth retraction reduced lip protrusion. Soft tissue profile was highly affected by lip protrusion [12] [16]. Orthodontic treatment altered lip position and lip protrusion because lips rested on hard tissue that were gradually altered during orthodontic treatment [13].

\section{Conclusion}

The result of this study showed that class II division I maloclussion treatment with upper premolar extractions followed by anterior teeth retraction increased interincisal angle and reduced the distance between line B and upper lip as well as lower lip position. These changes offered more esthetic face profile. 


\section{Conflicts of Interest}

The authors declare no conflicts of interest regarding the publication of this paper.

\section{References}

[1] Profit, W.R., Hendri, W.F. and David, M.S. (2013) Contemporary Orthodontics. 5th Edition, Elsevier Mosby, St Louis Missouri, 162-167.

[2] Rakosi, T., Irmtrud, J. and Thomas, M.G. (1993) Color Altlas of Dental Medicine. Thieme Medical Publishers, New York, 45-47, 198-200.

[3] Loi, H., Nakata, S., Nakisama, A. and Counts, A. (2005) Effect of Facial Convexity on A-P Lip Position of the Most Favoured Japanese Facial Profiles. The Angle Orthodontist, 75, 326-332.

[4] Agha, N.F., Zeina, M.A. and Zaid, B.A.D. (2011) Correlation of Incisors Inclination and Position with Facial Profile. Al-Rafidain Dental Journal, 11, 154-160.

[5] Kasai, K. (1998) Soft Tissue Adaptability to Hard Tissue in Facial Profiles. American Journal of Orthodontics and Dentofacial Orthopedics, 113, 674-687. https://doi.org/10.1016/S0889-5406(98)70228-8

[6] Hayashida, H., Hideki, I., Shunsuke, N., Ichiro, T. and Amy, L.C. (2010) Effects of Retraction of Anterior Teeth and Initial Soft Tissue Variables on Lip Changes in Japanese Adults . European Journal of Orthodontics, 33, 419-426. https://doi.org/10.1093/ejo/cjq095

[7] Erbay, E.F., Caniklioglu, C.M. and Erbay, S.K. (2002) Soft Tissue Profile in Anatolian Turkish Adult: Part 1. Evaluation of Horizontal Lip Position Using Different Soft Tissue Analyses. American Journal of Orthodontics and Dentofacial Orthopedics, 121, 57-64.

[8] Graber, T.M. and Vanarsdall, R.L. (1994) Orthodontics Current Principles and Technique. 5th Edition, Mosby Company, St Louis, 8-15.

[9] Holdaway, R.A. (1983) A Soft Tissue Cephalometric Analysis and Its Use in Orthodontic Treatment Planning. Part 1. American Journal Orthodontic, 84, 1-28.

[10] Konstantonis, D., Vasilelou, D., Ppageorgius, S.N. and Ellades, T. (2018) Soft Tissue Changes Following Extraction vs. Nonextraction Orthodontic Fixed Appliance Treatment: A Systematic Review and Meta-Analysis. Eupoean Journal of Oral Sciences, 1-13.

[11] Basciftci, F.A. and Usumez, S. (2003) Effect of Extraction and Nonextraction Treatment on Class I and Class II Subjects. The Angle Orthodontist, 73, 36-42.

[12] Hagler, B.L., Lupini, J. and Johnston, L.E. (1998) Long-Term Comparasion of Extraction and Nonextraction Alternatives in Matched Samples of African American Patient. American Journal of Orthodontics and Dentofacial Orthopedics, 114, 393 403.

[13] Kusnoto, J. and Kusnoto, H. (2001) The Effect of Anterior Tooth Retraction on Lip Position of Orthodontically Treated Adult Indonesians. American Journal of Orthodontics and Dentofacial Orthopedics, 120, 304-307.

[14] Talaas, M.F., Talaas, F. and Baker, R.C. (1987) Soft Tissue Changes Resulting from Retraction of Maxillary Incisors. American Journal of Orthodontics and Dentofacial Orthopedics, 91, 385-394. https://doi.org/10.1016/0889-5406(87)90391-X

[15] Rains, M.D. and Ravindra, N. (1982) Soft Tissue Changes Associated with Maxillary Incisor Retraction. American Journal of Orthodontics and Dentofacial Orthopedics, 
481-488.

[16] Kocadereli, I. (2002) Changes in Soft Tissue Profile after Orthodontic Treatment with and without Extraction. American Journal of Orthodontic and Dentofacial Orthopedics, 122, 67-72. 